\title{
Investigation of Friction Coefficients of Veneers as a Function of Fibre Direction and Moisture Content
}

\section{Istraživanje faktora trenja između furnira kao funkcije smjera protezanja vlakanaca i sadržaja vode}

\author{
Original scientific paper - Izvorni znanstveni rad \\ Received-prispjelo: 19. 2. 2018. \\ Accepted-prihvaćeno: 10. 12. 2018. \\ UDK: $630 * 812.13 ; 630 * 832.281 ; 630 * 832.282$ \\ doi: $10.5552 /$ drvind.2019.1806
}

\begin{abstract}
During the manufacture of veneer based moulded parts, veneers move against one another. Friction is caused due to this movement. Different conditions, such as gluing or fibre direction, could influence the friction coefficients and thus the moulding process. For a better understanding of the manufacturing process of veneer based moulded parts, it is important to know which parameters influence friction and friction coefficients. In this paper, results of friction investigations are presented. Thereby the moisture content of the used veneers was varied as well as the fibre direction. Considering the manufacture conditions, the investigations were also conducted with glue-coated veneers. The results prove an influence of fibre direction but this influence depends on moisture content.
\end{abstract}

Key words: veneer, friction, friction coefficients, wood moulded parts

SAŽETAK • Tijekom proizvodnje furnirskih otpresaka furniri se gibaju jedan nasuprot drugome. Zbog toga gibanja nastaje trenje. Različiti uvjeti kao što su lijepljenje i smjer protezanja vlakanaca mogu utjecati na faktor trenja, a time i na proces izrade otpresaka. Za bolje razumijevanje procesa proizvodnje furnirskih otpresaka važno je znati koji čimbenici utječu na trenje i faktor trenja. U ovom su radu prezentirani rezultati istraživanja trenja između furnira. Varirani su sadržaj vode upotrijebljenih furnira, kao i smjer protezanja vlakanaca. Uzimajući u obzir i proizvodne uvjete, istraživanje se provodilo is furnirima premazanim ljepilom. Rezultati su potvrdili utjecaj smjera protezanja vlakanaca, ali taj utjecaj ovisi o sadržaju vode u furniru.

Ključne riječi: furnir, trenje, koeficijent trenja, drveni otpresci

\section{INTRODUCTION 1. UVOD}

Moulded parts made of laminated wood are used as chair shells, built-in parts in sophisticated interior furnishing, loudspeaker enclosure or the like. In general, the manufacture of three-dimensional veneerbased moulded parts is conducted in heatable shaping presses. Thereby several veneer layers are stacked. During the moulding process, veneers shift against one another, causing friction. Depending on the layering of veneers (parallel or crosswise stacked veneer), there are different shift scenarios. The relative movement between veneer layers can also take place at an angle of $45^{\circ}$, depending on the used mould.

\footnotetext{
Authors are researcher and professor at Technical University in Dresden, Institute of Natural Materials Technology, Dresden, Germany.

' Autori su istraživač i profesor Tehničkog sveučilišta u Dresdenu, Institut za tehnologiju prirodnih materijala, Dresden, Njemačka.
} 
Investigations addressed to the friction of wood are mostly instigated by the wood machining process. Hence, these studies are focused on the friction between wood and metal (McKenzie, 1991; Seki et al., 2016; Svensson et al., 2009). The friction between wood and wood was investigated by McKenzie and Karpovich, 1968; Murase, 1984 and Ramananantoandro et al., 2007. Other studies are addressed wood based materials (Bejo et al., 2000; Seki et al., 2016).

In the referred studies, different influencing variables were considered, such as sliding speed, normal load, temperature, moisture content or fibre direction. In each study different wood species were used. All scientists in the referred studies have determined the static $\left(\mu_{s t}\right)$ and sliding $\left(\mu_{s l}\right)$ friction coefficient.

The influence of sliding speed was investigated by McKenzie and Karpovich (1968) and Ramananantoandro et al. (2007). McKenzie and Karpovich (1968) have presented a basic study concerning the friction of wood. They investigated a variety of wood species. A milling machine was used for applying friction to the wood. The use of a milling machine indicates the background of these investigations: friction and wear during the wood machining process. The sliding speed was varied between 0 and $2000 \mathrm{~mm} / \mathrm{min}$. Ramananantoandro et al. (2007) conducted friction tests with oak with a newly developed friction testing machine that performs the friction by a linear movement. Whereas McKenzie and Karpovich (1968) found an influence of sliding speed on friction coefficients, Ramananantoandro et al. (2007) could not ascertain an influence.

The influence of the normal load was investigated by Ramananantoandro et al. (2007) and Murase (1984). Murase (1984) has conducted friction tests with Western hemlock. Murase has varied the normal load between $2.3 \mathrm{kPa}$ and $65 \mathrm{kPa}$, and Ramananantoandro et al. (2007) between $23 \mathrm{kPa}$ and $228 \mathrm{kPa}$. According to both studies, the friction coefficients are independent of the normal load.

The influence of moisture content was the object of investigations conducted by McKenzie and Karpovich (1968) and Murase (1984). McKenzie and Karpovich (1968) investigated wood conditioned to $12 \%$ moisture content and wet, water soaked and dripping wood. The main conclusion concerning the woodwood friction resulting from their study was that water soaked samples have clearly higher friction coefficients than wood with $12 \%$ moisture content. They did not differentiate between the varieties of wood species they had investigated. Murase (1984) has varied the moisture content of wood between air dry and water saturation in four steps. He has confirmed the results of McKenzie and Karpovich (1968) and found that both friction coefficients increase when moisture content increases. Murase (1984) explained that the increase in friction coefficients with increasing moisture content is due to a higher adhesion between wood and wood. The hydrogen bonding is considered to be responsible for this adhesion.

The fibre direction, as an influencing variable, was investigated by McKenzie and Karpovich (1968) and Ramananantoandro et al. (2007). McKenzie and Karpovich (1968) have investigated three sliding situations: a) surface parallel to the fibre direction, sliding parallel to the fibre direction; b) surface parallel to the fibre direction, sliding perpendicular to the fibre direction (cross-cut); c) surface perpendicular to the fibre direction (cross-cut), sliding perpendicular to the fibre direction (cross-cut). They have found only small differences due to fibre orientation. Thus, all results were averaged. Ramananantoandro et al. (2007) have determined friction coefficients at different anatomical planes and directions, but the fibre and sliding direction from unmoved and moved surfaces were always the same. They have concluded that the fibre direction has no influence on the static frictional behaviour, while influence was observed on the sliding frictional behaviour. Thus, in the considered fibre directions of both studies, no influence of the fibre direction on the static friction coefficient could consistently be found. Considering the sliding frictional behaviour, Ramananantoandro et al. (2007) have found an influence, while McKenzie and Karpovich (1968) could not find any influence. However, both authors have investigated different fibre directions and situations of unmoved and moved planes.

The literature review consistently confirms the independence of friction coefficients on the normal load. Also, the dependence of moisture content was consistently confirmed. There are contradictions about the influence of fibre direction and sliding speed.

Considering the above mentioned background of these investigations, in this study friction coefficients for the moulding process of stacked veneer layers were determined. Subsequently, these coefficients shall be used for modelling this process. Thereby, the investigated influencing parameters were chosen to be similar to conditions occurring during the moulding process. Different combinations of movement directions were investigated considering the manufacture of three dimensional, veneer-based moulded parts. Such combinations of fibre and sliding direction are not known from literature.

To achieve higher degrees of deformation, veneers are mostly moistened. Furthermore, the veneers have to be glued for manufacturing moulded parts. That is why different moisture conditions and glued veneers were investigated.

\section{MATERIALS AND METHODS} 2. MATERIJALI I METODE

Industrial sliced beech veneer (Fagus sylvatica L.; $1.2 \mathrm{~mm}$ thick) was used for the investigations because it represents the most commonly used species for manufacturing veneer based moulded parts. Industrially produced veneers do not have a strictly anatomically oriented surface. The created plane is a cross of the longitudinal plane in one direction and the radial and tangential plane in the other direction. Hence, the tests were conducted with veneers of the L-RT plane. Friction tests were conducted referring to DIN EN 


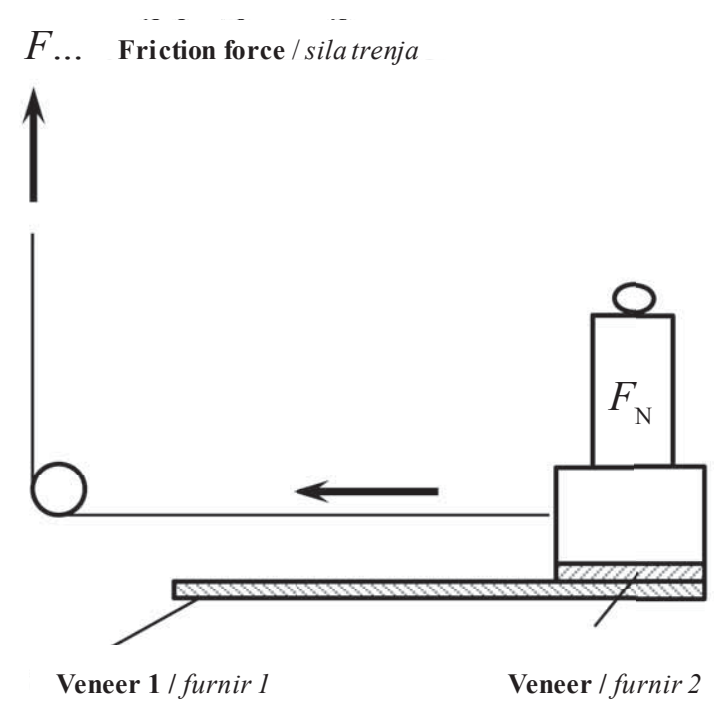

Figure 1 Schematic diagram of friction test apparatus Slika 1. Shematski prikaz uređaja za ispitivanje trenja

14882 (2005) (Figure 1) in a standard atmosphere at $20{ }^{\circ} \mathrm{C}, 65 \% \mathrm{rh}$.

The bottom veneer (veneer 1) was the stationary counterpart. Its dimensions were $70 \mathrm{~mm}$ x $130 \mathrm{~mm}$. The moving veneer (veneer 2) was pulled across the stationary veneer with a constant normal load and sliding speed. The arrows show the direction of movement. The moved veneer had dimensions of $50 \mathrm{~mm} \mathrm{x}$ $50 \mathrm{~mm}$ and was fixed to a block. This veneer was pulled over a distance of $100 \mathrm{~mm}$ across its counterpart, veneer 1. During this movement, the load F was measured. This load is considered to determine the friction force. The load peak $\left(F_{s t}\right)$, occurring just before the movement, was used for calculating the static friction coefficient $\mu_{\mathrm{st}}$ (Eq. 1).

$$
\mu_{\mathrm{st}}=\frac{F_{\mathrm{st}}}{F_{\mathrm{N}}}
$$

The normal load $F_{N}$ amounted to $59 \mathrm{~N}$.

In order to calculate the sliding friction coefficient $\mu_{s l}$, all load values between $10 \mathrm{~mm}$ and $100 \mathrm{~mm}$ during the sliding process were averaged. The values below $10 \mathrm{~mm}$ were not considered in order to exclude the influence of the sliding start. The coefficient was calculated in analogy to Eq. 1, as follows:

$$
\mu_{\mathrm{sl}}=\frac{F_{\mathrm{sl}}}{F_{\mathrm{N}}}
$$

According to different scenarios of movements and fibre directions in a veneer batch during the moulding process, different sliding situations were investigated (Figure 2). The sliding situation describes the fibre directions relative to the sliding direction. The large arrow in Figure 2 indicates the direction of movement (sliding direction). The lines in the veneer illustrations indicate the fibre direction. $0^{\circ}$ means the fibre direction of the veneer is the same direction as the sliding direction; $90^{\circ}$ means the fibre direction runs $90^{\circ}$ in relation to the sliding direction, $45^{\circ}$ means the angle between fibre direction and sliding direction amounts to $45^{\circ}$.

Friction coefficients were determined on airdried samples (air-conditioned at $20{ }^{\circ} \mathrm{C} / 65 \%$ rel. humidity, $\omega=11.7 \%$ ), on water-saturated samples (water logged for $24 \mathrm{~h}$; surface water dapped, $\omega=83 \%$ ) and veneers coated with adhesive. For the last sliding situation, the lower veneer (veneer 1) was coated with UF resin KAURIT ${ }^{\circledR}$ glue 325 fluid. The veneer was coated with $180 \mathrm{~g} / \mathrm{m}^{2}$ glue. The moved veneer (veneer 2) was not coated with glue; it was air-dried at $20{ }^{\circ} \mathrm{C} / 65 \% \mathrm{rh}$.

Every sliding situation was conducted 5 times, whereas each veneer was used only once. The veneer surfaces were damaged during the friction tests thus each test had to be conducted with new veneer samples. The sliding speed amounted to $400 \mathrm{~mm} / \mathrm{min}$.

\section{RESULTS AND DISCUSSION}

\section{REZULTATI I RASPRAVA}

Figure 3a-c and Figure 4a-c show the test results. Basically, the static friction coefficient is higher than the sliding friction coefficient. That was to be expected, considering the literature. McKenzie and Karpovich (1968) determined a coefficient of static friction $\left(\mu_{s t}\right)$ of 0.6 and a coefficient of sliding friction $\left(\mu_{s l}\right)$ of 0.45 for wood with a moisture content of $12 \%$. Concerning the water soaked samples, $\mu_{s t}$ was determined

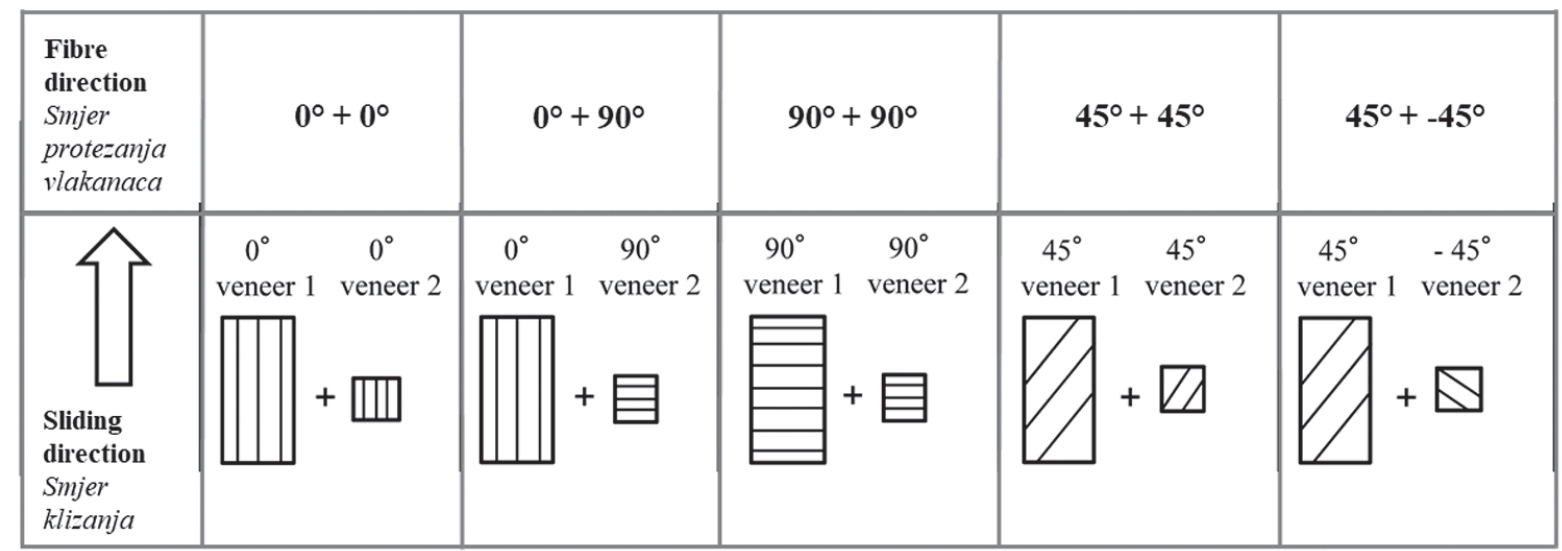

$0^{\circ} ; 90^{\circ} ; 45^{\circ} \ldots$ Fibre direction to sliding direction / smjer prtezanjavlakanacau odnosu prema smjeru klizanja

Figure 2 Combinations of fibre directions and their denotation

Slika 2. Kombinacije smjera vlakana i njihove oznake 
to be 0.85 and $\mu_{s l}$ varied between 0.38 and 0.64 , depending on sliding speed. Murase (1984) determined the static friction coefficient $\mu_{s t}$ to be at 0.8 and the sliding friction.

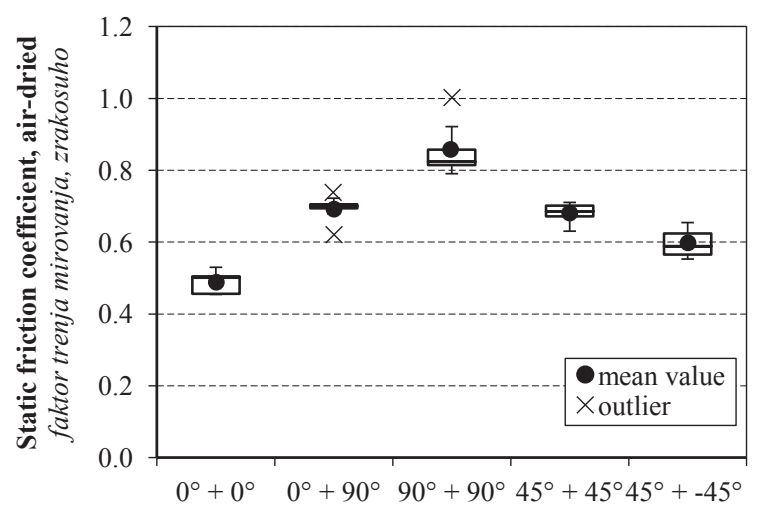

Fibre direction / smjer protezanja vlakanaca

Figure 3a Static friction coefficients of air-dried samples Slika 3.a) Faktor trenja mirovanja zrakosuhih uzoraka

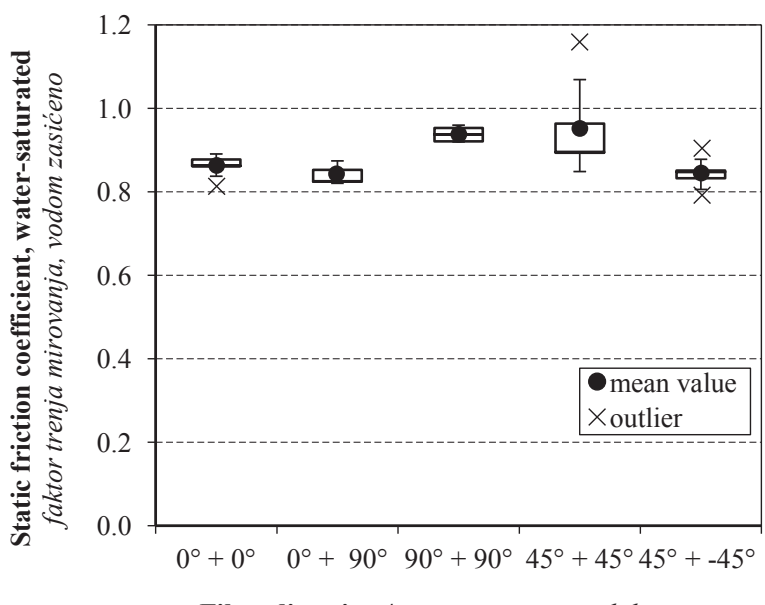

Fibre direction / smjer protezanja vlakanaca

Figure 3b Static friction coefficients of water-saturated samples

Slika 3.b) Faktor trenja mirovanja uzoraka zasićenih vodom

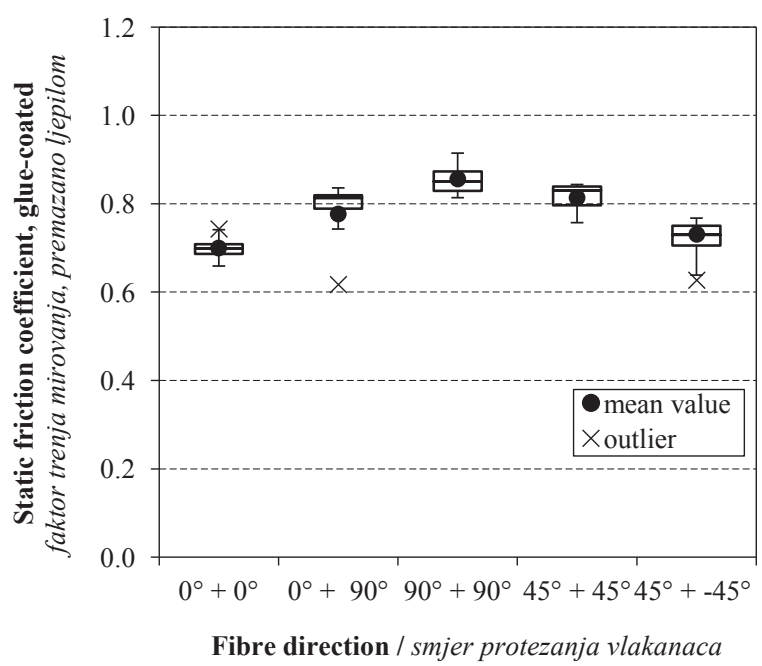

Figure 3c Static friction coefficients of adhesive-coated samples

Slika 3.c) Faktor trenja mirovanja uzoraka premazanih ljepilom
The comparison of different sliding situations shows an influence of fibre direction on friction coefficients. The ANOVA-test $(p<0.05)$ results in the proof

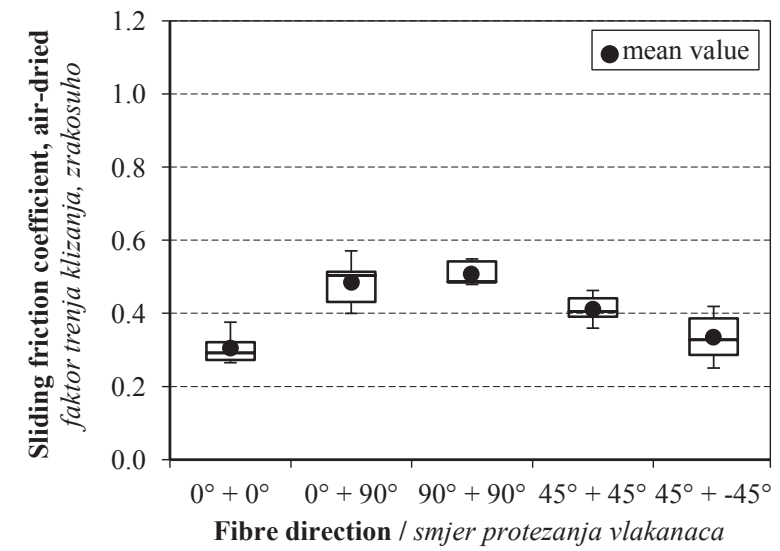

Figure 4a Sliding friction coefficients of air-dried samples Slika 4.a) Faktor trenja klizanja zrakosuhih uzoraka

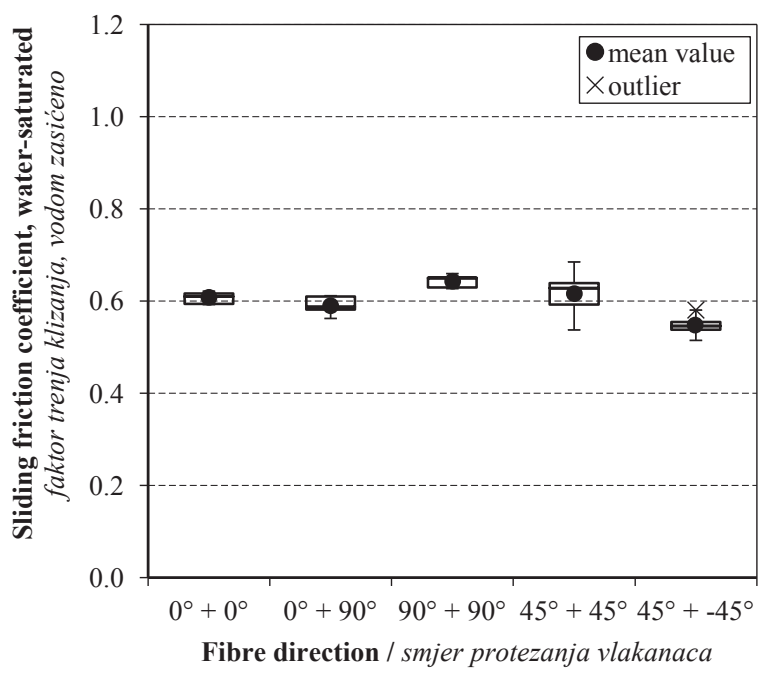

Figure $4 \mathrm{~b}$ Sliding friction coefficients of water-saturated samples

Slika 4.b) Faktor trenja klizanja uzoraka zasićenih vodom

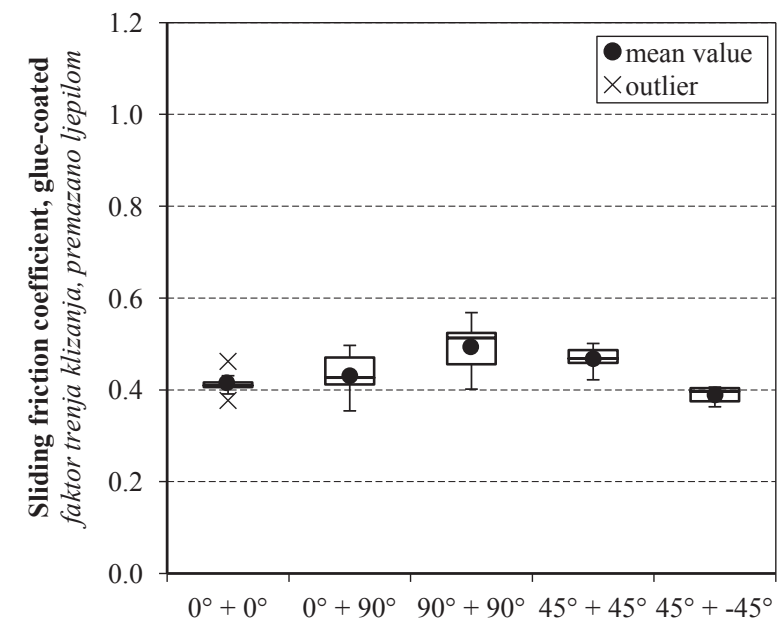

Fibre direction / smjer protezanja vlakanaca

Figure 4c Sliding friction coefficients of adhesive-coated samples

Slika 4.c) Faktor trenja klizanja uzoraka premazanih ljepilom 
of significant differences between the mean values of the friction coefficients of the tested sliding situations. This statistical significance could be proven for static as well as for sliding friction for air-dried, water-saturated and adhesive-coated samples. Thereby, the airdried samples show the clearest differences between the various sliding situations. The highest friction values were obtained by movement of two surfaces in the fibre direction of $90^{\circ}$.

According to the available literature, the combinations of fibre and sliding direction (the sliding situations) measured in this study have never been measured before. In this respect the results cannot be compared with literature values (McKenzie and Karpovich, 1968; Ramananantoandro et al., 2007).

Basically, the results of this study prove differences of friction coefficients when different fibre directions slide over each other. Previous studies did not result in such clear differences.
The friction coefficients of water-saturated samples are clearly higher than the coefficients of the airdried samples. That was basically also to be expected, considering the literature, but the known findings could be extended for the regarded sliding situations.

An interesting fact is that the results indicated only small differences between the sliding situations.

In contrast to the air-dried samples that were sliding continuously, all water-saturated samples showed a slip-stick effect. That means a continuous jerking occurred, which might be regarded as alternating between static and sliding friction. Figure 5a shows an example of measuring values of a smooth-running air-dried sample, and Figure 5b of a water-saturated sample with slip-stick. The diagram shows that sliding force peaks reach or approach the initial force required to set the specimen in motion, which indicates that the specimen repeatedly stopped during the test. This effect might amplify the sliding friction coefficients because this

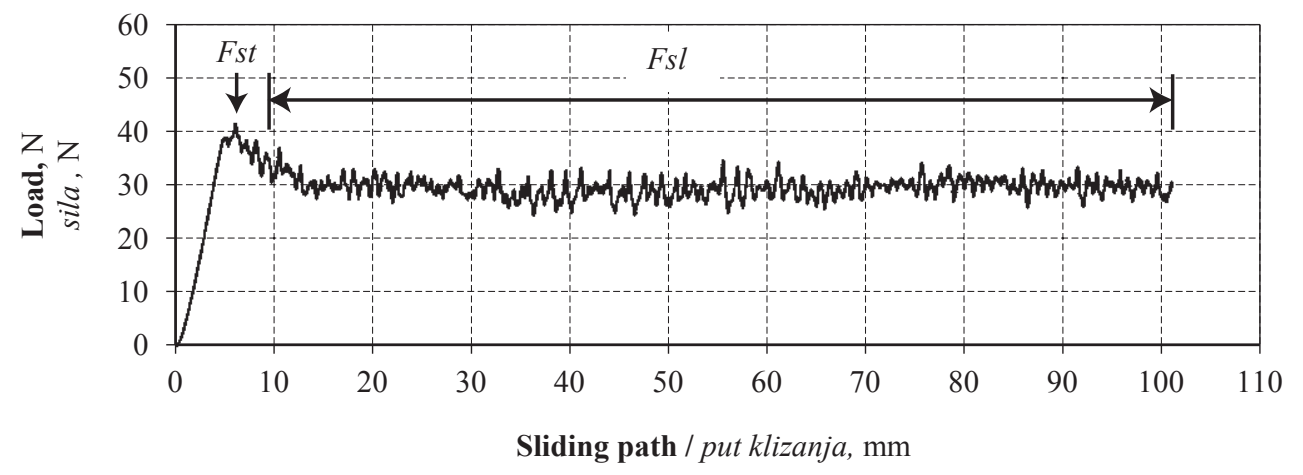

Figure 5a Behaviour of friction force (exemplarily) of air-dried samples Slika 5.a) Ponašanje sile trenja (kao primjer) zrakosuhih uzoraka

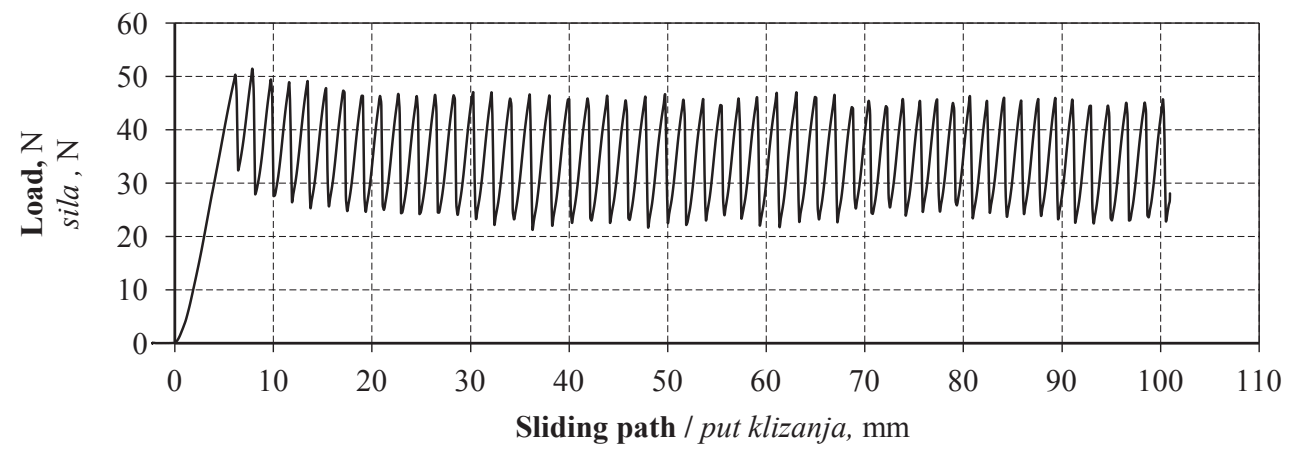

Figure 5b Behaviour of friction force (exemplarily) of water-saturated samples Slika 5.b) Ponašanje sile trenja (kao primjer) uzoraka zasićenih vodom

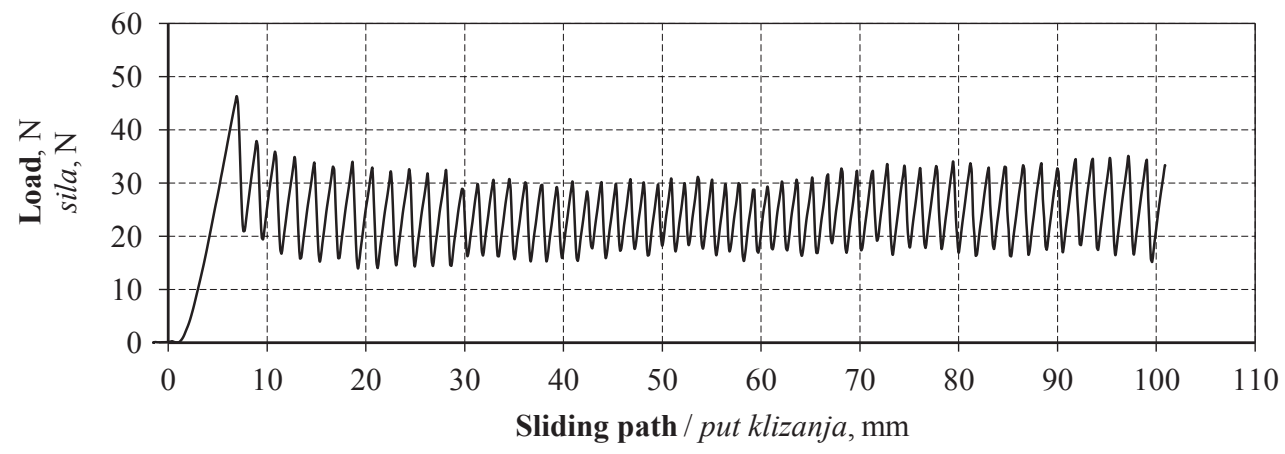

Figure 5c Behaviour of friction force (exemplarily) of glue-coated samples Slika 5.c) Ponašanje sile trenja (kao primjer) uzoraka premazanih ljepilom 
coefficient is averaged using all load values. McKenzie and Karpovich (1968) and Murase (1984) explain the higher coefficients of wet samples with some additional hydrogen bonding between the two counterparts. The additional hydrogen bonding might be one reason, but other things might increase the friction of watersaturated samples, as well. Due to the high moisture content of wet samples, the samples are swollen. Because of the raised fibres, the roughness is increased (Csanády et al., 2015). Although Ramananantoandro (2007) could not prove a correlation between roughness and friction coefficients, an obstruction of the movement due to raised fibres is conceivable.

Furthermore, the water softens the veneers. Thus, the upper (moving) veneer can be pressed into the counterpart veneer by the normal load, generating a dent. Therefore, a higher drag is created against the movement. That might also explain the slip-stick: the sample sinks in causing it to stop and high power is necessary to restart the movement (power peak); then the sample stops because of sinking in again.

The friction coefficients of the samples coated with adhesive behave similarly to the water-saturated samples in terms of differences of fibre directions, but the friction coefficients are lower. The differences between the sliding situations are clearly reduced. $80 \%$ of the tests showed a slip-stick. Figure $5 \mathrm{c}$ shows a sample diagram. The adhesive layer is very thin. Part of the adhesive will certainly be absorbed by the surface and soften the surface like the water-saturated samples. Probably, therefore, the adhesive cannot undertake the function of a lubricant. A possible reason for the slipstick effect of these samples is the additional adhesion between wood and adhesive that the UF resin elicits. In contrast to water, the adhesive is sticky and thus inhibits the motion.

The results show that neither the water nor the glue act as lubricants. The friction is increased by using either of the two fluids. Independently of the kind of the fluids between the friction counterparts, the differences between the fibre directions are clearly reduced due to the presence of fluids. Nevertheless, the differences are statistically significant.

\section{CONCLUSIONS}

\section{ZAKLJUČAK}

The following conclusions can be drawn:

- The sliding situation and the fibre direction have an influence on the friction. This influence depends on moisture content.

- The differences between the friction coefficients are clearly reduced by water-saturated samples and samples coated with adhesive. Thus, the moisture equalizes the coefficients, but it also increases the friction.
- The glue layer does not work as a lubricant. The friction is increased due to the fluid adhesive. The presence of adhesive elicits a slip-stick-effect by most of the investigated samples.

\section{Acknowledgements - Zahvala}

The research project based on these investigations was financially supported by the Federal Ministry of Economics and Technology of Germany (Grant Reference $18557 \mathrm{BR}$ ).

\section{REFERENCES}

5. LITERATURA

1. Bejo, L.; Lang, E. M.; Fodor, T., 2000: Friction coefficients of wood-based structural composites. Forest Products Journal, 50: 39-43.

2. Csanády, E.; Magoss, E.; Tolvvaj, L., 2015: Quality of Machined Wood Surfaces. Springer. Cham Heidelberg New York Dordrecht London.

3. McKenzie, W. M.; Karpovich, H., 1968: The frictional behaviour of wood. Wood Science and Technology, 2: 139-152. https://doi.org/10.1007/BF00394962.

4. McKenzie, W. M., 1991: Friction coefficient as a guide to optimum rake angle in wood machining. Wood Science and Technology, 25: 397-401. https://doi.org/10.1007/BF00226179.

5. Murase, Y., 1984: Friction of Wood Sliding on Various Materials. Journal of the Faculty of Agriculture - Kyushu University, 28 (4): 147-160.

6. Ramananantoandro, T.; Eyma, F.; Paris, J.-Y.; Denape, J., 2007: Linear measurement of friction parameters on oak pedunculate as related to wood ligneous plane. Proceedings of Third International Symposium on Wood Machining: 93-96.

7. Seki, M.; Tanaka, S.; Miki, T.; Shigematsu, I.; Kanayama, K., 2016: Friction characteristics between metal tool and wood impregnated with phenol formaldehyde (PF) resin during exposure to high pressure. Journal of Wood Science, 62: 233-241. https://doi.org/10.1007/s10086-016-1551-x.

8. Svensson, B.; Nyström, S.; Gradin, P.; Höglund, H., 2009: Frictional testing of wood-Initial studies with a new device. Tribology International, 42: 190-196. https:// doi.org/10.1016/j.triboint.2008.03.009.

9. ***DIN EN 14882, 2005: Rubber or plastic coated fabrics; Determination of the static and dynamic coefficient of friction. DIN German Institute of Standardization. Berlin.

\section{Corresponding address:}

\section{Dipl. Ing. BEATE BUCHELT}

Technische Universität Dresden

Institute of Natural Materials Technology

01069 Dresden, GERMANY

e-mail: beate.buchelt@tu-dresden.de 